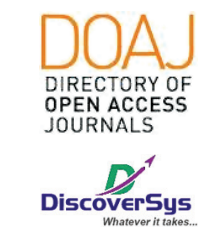

Published by DiscoverSys

\section{Efektivitas multi drug therapy pada transmisi morbus hansen transplasental}

\author{
Dhelya Widasmara, ${ }^{1 *}$ Santosa Basuki, ${ }^{1}$ Dea Florensia, ${ }^{1}$ Ade Setyagraha ${ }^{2}$
}

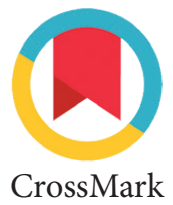

CrossMark

\section{ABSTRACT}

Introduction: The evidence of transplancental transmission of Morbus Hansen (MH) in animal models is a challenge for MH treatment in pregnancy because it brings anxiety for patients and their fetuses. Case: A 31-year-old pregnant woman, first trimester, came with complaints of reddish numbness rash on her hands since 2 years ago. Dermatological examination showed erythematous plaque, multiple, well-defined, irregular borders with hypoaesthesia. There were right and left ulnar nerve enlargement. Acid Fast Bacteria (AFB) from ear lobes and lesion revealed Bacterial Index +2 and Morphological

Index 10\%. Histopathological examination showed gren zone which indicate MH type BL. Patient was diagnosed with MH Multi Basiler (MB) on G3P2002Ab000 and given MDT MHMB. Postpartum IgM and $\lg$ G anti-PGL-1 examination of cord blood and infant blood, also PCR examination of cord blood and amnion showed negative results. Histopathological examination found no AFB on the umbilical cord and placenta.

Conclusion: MDT is effective in preventing transplacental transmission of MH from mother to fetus.

Keywords: Morbus Hansen, pregnancy, treatment, outcome.

Cite This Article: Widasmara, D., Basuki, S., Florensia, D., Setyagraha, A. 2020. Efektivitas multi drug therapy pada transmisi morbus hansen transplasental. Intisari Sains Medis 11(2): 425-428. D0l: 10.15562/ism.v11i2.713

\title{
ABSTRAK
}

Pendahuluan: Adanya bukti transmisi Morbus Hansen (MH) transplasental pada model hewan merupakan suatu tantangan pengobatan $\mathrm{MH}$ pada kehamilan karena membawa kekhawatiran tersendiri bagi penderita dan janin yang dikandungnya.

Kasus: Seorang perempuan berusia 31 tahun, dengan kehamilan trimester 1, datang dengan keluhan bercak kemerahan mati rasa di tangan sejak 2 tahun yang lalu. Pemeriksaan dermatologis menunjukkan plak eritematus, multipel, batas tegas, tepi ireguler dengan hipoestesi. Didapatkan pembesaran saraf ulnaris dekstra dan sinistra. Pemeriksaan Bakteri Tahan Asam (BTA) dari cuping telinga dan lesi didapatkan Bacterial Index +2 dan Morphological Index 10\%. Pemeriksaan histopatologis tampak gren zone yang menunjukkan MH tipe BL. Pasien didiagnosis MH Multi Basiler (MB) dengan G3P2002Ab000 dan diberikan MDT MHMB. Pemeriksaan IgM dan IgG anti PGL-1 post partum dari darah tali pusat dan darah bayi, serta pemeriksaan PCR darah tali pusat dan amnion didapatkan hasil negatif. Tidak didapatkan BTA pada pemeriksaan histopatologis tali pusat dan plasenta.

Simpulan: MDT efektif dalam mencegah transmisi MH transplasental dari ibu ke janin.
'Departemen/SMF Dermatologi dan Venereologi, Fakultas Kedokteran Universitas Brawijaya/ Rumah Sakit Umum Daerah Dr. Saiful Anwar, Malang, Indonesia ${ }^{2}$ Departemen/SMF Obstetri Ginekologi, Fakultas Kedokteran Universitas Brawijaya/Rumah Sakit Umum Daerah Dr. Saiful Anwar, Malang, Indonesia

*Korespondensi: Dhelya Widasmara, Departemen/SMF Dermatologi dan Venereologi, Fakultas Kedokteran Universitas Brawijaya/Rumah Sakit Umum Daerah Dr. Saiful Anwar, Malang, Indonesia dhelyawidasmara@ub.ac.id

Diterima: $13-02-2020$

Disetujui: $13-05-2020$

Diterbitkan: 21-05-2020

\section{Kata kunci: Morbus Hansen, kehamilan, terapi, Iuaran klinis.}

Cite Pasal Ini: Widasmara, D., Basuki, S., Florensia, D., Setyagraha, A. 2020. Efektivitas multi drug therapy pada transmisi morbus hansen transplasental. Intisari Sains Medis 11(2): 425-428. D0I: 10.15562/ism.v11i2.713

\section{PENDAHULUAN}

Morbus Hansen (MH) atau penyakit MH merupakan salah satu penyakit menular dan kronis yang hingga saat ini masih menimbulkan masalah yang kompleks. ${ }^{1} \mathrm{MH}$ adalah penyakit yang menyerang saraf tepi, kulit dan jaringan tubuh lainnya, kecuali sistem saraf pusat. Menurut data World Health Organization (WHO) tahun 2014 prevalesi MH di dunia adalah 213.899 kasus. $^{2}$ Indonesia menempati urutan ke-3 setelah India dan Brazil. Di Indonesia, berdasarkan data Kementrian Kesehatan RI tahun 2013, tercatat 16.825 kasus MH baru. ${ }^{3}$
Sepertiga dari kasus baru tersebut terjadi pada populasi perempuan usia subur atau reproduksi. ${ }^{4}$

MH pada kehamilan merupakan suatu keadaan yang kompleks. ${ }^{5}$ Pada kehamilan terjadi perubahan fisiologi, hormonal, metabolisme dan perubahan respon imun yang menyebabkan perempuan hamil berisiko tinggi mengalami infeksi $\mathrm{MH}$ atau mengalami perubahan perjalanan penyakit $\mathrm{MH}$ yang sebelumnya sudah ada. Kehamilan merupakan salah satu faktor predisposisi terjadinya relaps pada infeksi MH subklinis maupun yang sudah diobati. ${ }^{6}$ 
Kehamilan dengan $\mathrm{MH}$ membutuhkan perhatian khusus, mengingat infeksi MH memberikan dampak bagi ibu maupun janin. Adanya bukti transmisi $\mathrm{MH}$ transplasental pada model hewan membawa kekhawatiran tersendiri bagi penderita dan keluarga, serta terhadap janin yang dikandungnya. Tujuan penulisan kasus ini untuk menunjukkan efektivitas MDT pada transmisi MH transplasental. Manfaat penulisan kasus ini adalah untuk menambah pengetahuan mengenai kehamilan dengan $\mathrm{MH}$ dan hal-hal perlu diwaspadai agar dapat berguna dalam penanganan kasus serupa di kemudian hari.

\section{LAPORAN KASUS}

Seorang perempuan usia 31 tahun datang ke klinik Kulit dan Kelamin Rumah Sakit Umum Daerah (RSUD) Saiful Anwar (RSSA) Malang dengan keluhan utama bercak kemerahan mati rasa pada punggung tangan dan ibu jari tangan kiri. Pasien juga mengeluh kesemutan pada telapak tangan kiri yang dirasakan sejak 1 bulan lalu. Keluhan berupa demam, kulit terasa kering, penglihatan kabur, nyeri pada mata, atau kerontokan alis mata disangkal. Pasien saat ini sedang hamil anak ketiga, usia kehamilan 6 minggu. Pasien selama ini memeriksakan kehamilannya di bidan puskesmas.

Pasien mengaku tidak pernah mengalami keluhan seperti ini sebelumnya. Pasien juga menyangkal memiliki riwayat penyakit lain sebelumnya. Riwayat keluhan yang sama pada suami, anak pasien, orang tua, keluarga pasien, maupun keluarga suami pasien disangkal.

Pasien saat ini tinggal dengan suami dan 2 anaknya. Pasien merupakan suku Sunda, sempat tinggal

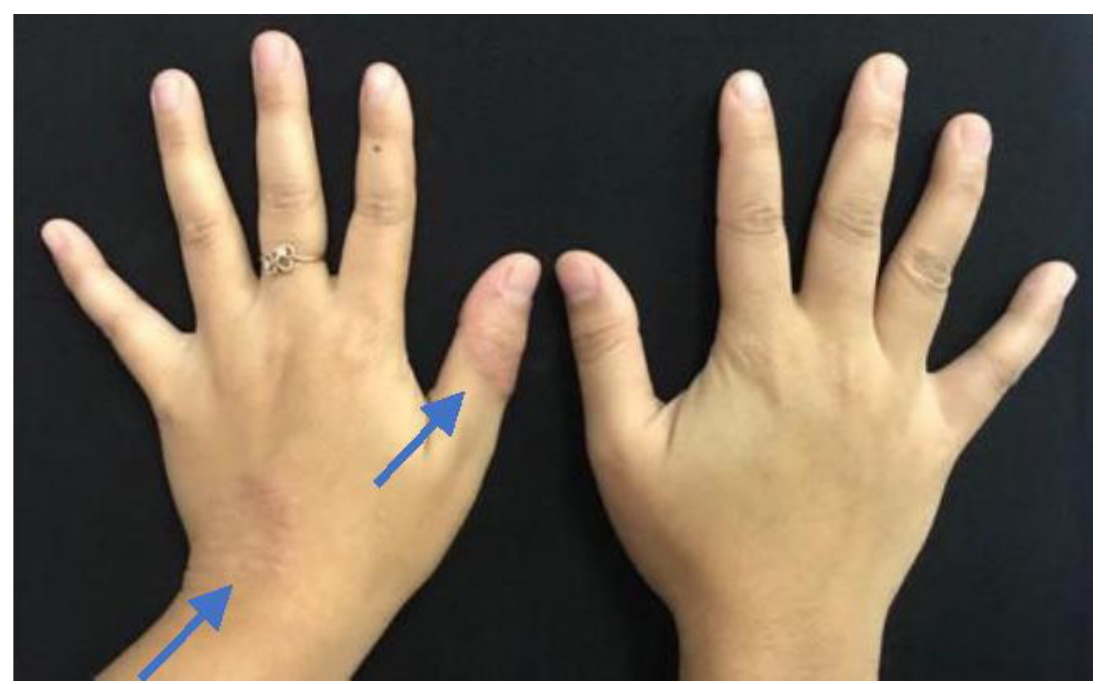

Gambar 1 Pemeriksaan Dermatologis Dorsum Manus. Didapatkan plak eritematus, multipel, batas tegas, tepi iregular, ukuran dan bentuk bervariasi ( $\left.{ }^{\circledR}\right)$ pada dorsum manus sinistra dam digiti 1 manus sinistra
8 bulan di Madura setelah menikah dengan suami suku Madura, kemudian menetap di Malang sejak 7 tahun lalu. Pasien mengatakan bahwa saat tinggal di Madura, tetangga pasien kemungkinan juga ada yang mengalami keluhan seperti ini namun tidak diperiksakan. Pasien dan suaminya bekerja sebagai penjual sate.

Pemeriksaan generalisata dalam batas normal. Pemeriksaan dermatologi didapatkan lesi plak eritematus, multipel, batas tegas, tepi ireguler, ukuran dan bentuk bervariasi pada dorsum manus sinistra dan digiti 1 manus sinistra (Gambar 1). Tidak didapatkan infiltrat pada regio cuping telinga kiri dan kanan. Tidak didapatkan facies leonine maupun madarosis pada regio fasialis.

Pemeriksaan palpasi saraf didapatkan penebalan pada nervus ulnaris dekstra dan sinistra. Pemeriksaan sensoris rasa raba, nyeri, dan suhu didapatkan hipoestesi pada lesi di dorsum manus sinistra dan pada digiti I manus sinistra.

Pemeriksaan BTA dari cuping telinga dan lesi didapatkan Indeks Bakteriologis (BI) +2 dan Indeks Morfologis (MI) 10\% (Gambar 2).

Pemeriksaan histopatologi dari plak eritematus di daerah dorsum manus sinistra menunjukkan area aseluler diantara epidermis dan dermis (Gren zone). Pada dermis terdapat sebaran dan kelompok-kelompok sel-sel radang, limfosit, histiosit, epitheloid, makrofag dan multinucleated giant cell yang membentuk granuloma-granuloma dan tampak debris-debris neutrofil beberapa terlihat mengelilingi kelenjar-kelenjar dan pembuluh darah, diantaranya tampak jaringan ikat fibrokolagen, yang mendukung gambaran $\mathrm{MH}$

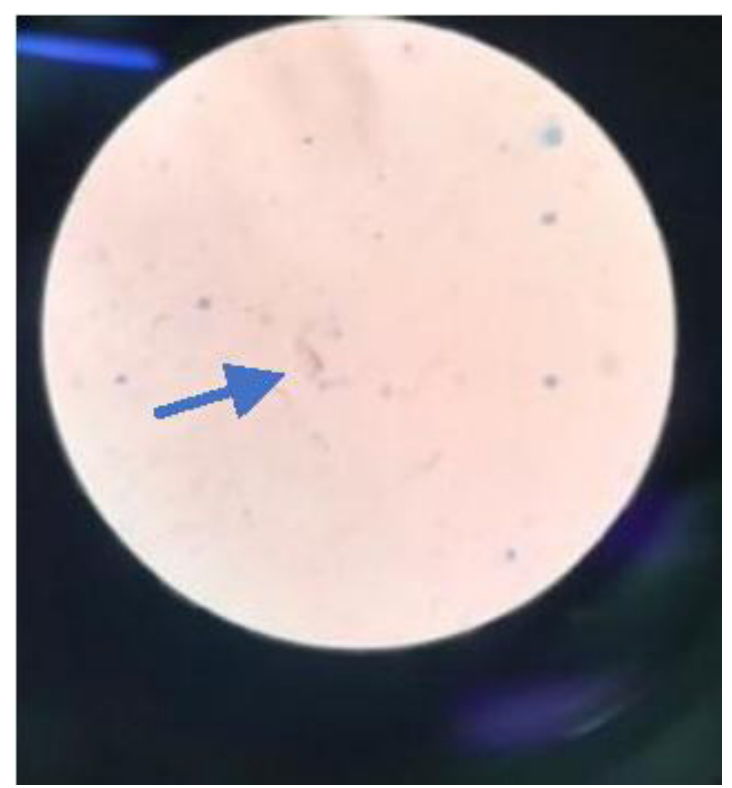

Gambar 2 Pemeriksaan BTA dengan Pembesaran 1000x. Pada cuping telinga didapatkan bakteri tahan asam $\left(^{\circ}\right)$ 


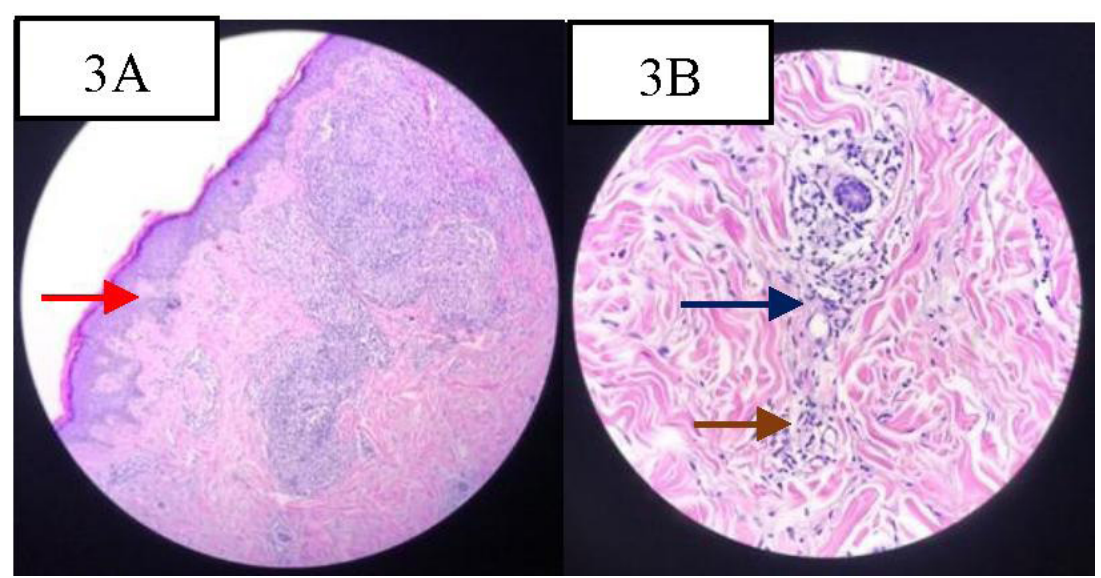

Gambar 3 Pemeriksaan Histopatologi. 3A) Didapatkan green zone (). 3B) Pada dermis didapatkan kelompok-kelompok sel epithelioid histiosit (), foamy makrofag () tersusun membentuk granuloma diantaranya terdapat jaringan ikat dengan sebaran sel radang limfosit (Hematoksilin \& Eosin, 400x)

tipe Borderline Leprosy (BL) menurut kriteria Ridley-Jopling.

Berdasarkan anamnesis, pemeriksaan fisik dan pemeriksaan penunjang, pasien didiagnosis $\mathrm{MHMB}$ dengan G3P2002Ab000 dengan derajat kecacatan 0 menurut WHO. Pasien diberikan pengobatan MDT MH MB (Rifampisin $600 \mathrm{mg} /$ bulan, Klofazimin 300 mg/bulan, Klofazimin 100 mg/hari, Dapson $50 \mathrm{mg} / \mathrm{hari}$ ) mulai trimester 2. Pasien diberikan edukasi mengenai penyakit, hasil pemeriksaan, aturan konsumsi obat, pentingnya kontrol rutin, dan kemungkinan terjadinya reaksi selama kehamilan sebelum, saat, dan setelah pengobatan.

Pasien dikonsultasikan ke departemen Obstetri dan Ginekologi untuk pemeriksaan antenatal dan didiagnosis dengan G3P2002Ab000 gravida 6-8 minggu tunggal hidup dengan $\mathrm{MH}$ MB. Tidak didapatkan adanya kelainan dari pemeriksaan ultrasonografi (USG). Pasien diberikan suplementasi yang mengandung asam folat, tablet besi sulfat, dan kalsium.

Pasien partus secara spontan pada kehamilan minggu ke 39-40. Pemeriksaan IgM dan IgG anti PGL-1 paska melahirkan dari darah tali pusar dan darah bayi menunjukkan hasil seronegatif dengan titer $<605 \mathrm{~m} / \mathrm{mL}$. Pemeriksaan PCR darah tali pusat dan amnion didapatkan hasil negatif. Pemeriksaan histopatologi dari tali pusat dan plasenta tidak didapatkan BTA. Tidak didapatkan neuritis dan reaksi $\mathrm{MH}$ sampai 3 bulan paska melahirkan, serta tidak didapatkan efek samping penggunaan MDT pada bayi.

\section{DISKUSI}

Secara global dari 2000 pasien yang dideteksi MH per tahun, sebanyak 2 hingga 3 orang adalah perempuan hamil dan mayoritas didiagnosa pada saat trimester ketiga. ${ }^{5}$ Pasien dengan usia kehamilan 6-8 minggu secara fisiologis mengalami kondisi imunosupresi oleh karena adanya gangguan imunologis, nutrisi, dan gangguan sekresi steroid yang menyebabkan penurunan sistem imunitas selular. Hal ini ditandai dengan adanya penurunan respon proinflamasi Th1 (berhubungan dengan kegagalan kehamilan) dan peningkatan respon antiinflamasi Th2 (bersifat protektif terhadap kehamilan) yang mengakibatkan menurunnya respon protektif terhadap infeksi, terutama bakteri intraselular (karena dimediasi oleh respon Th1), sehingga meningkatkan kerentanan ibu hamil terhadap infeksi M. Leprae. Meskipun mekanisme pastinya belum diketahui, namun perubahan respon Th1 menjadi Th2 dipengaruhi oleh peningkatan kadar estrogen dan progesteron selama hamil.

Kondisi malnutrisi relatif akibat peningkatan kebutuhan selama kehamilan menyebabkan peningkatan respon imun dimediasi Th2 sehingga terjadi perburukan infeksi. Suplementasi mikronutrien mengubah respon imun Th2 menjadi Th1 sehingga meningkatkan imunitas alamiah dan menjaga respon imunitas protektif Th1 terhadap infeksi. ${ }^{8}$

Gangguan sekresi steroid saat kehamilan juga berperan dalam depresi sistem imunitas selular karena terdapat peningkatan kadar kortisol bebas dan 17-hidroksikortikosteroid yang mengakibatkan eksaserbasi MH saat kehamilan. Periode imunosupresi pada kehamilan terjadi antara trimester terakhir kehamilan dan 3 bulan paska melahirkan, yang akan meningkatkan kecenderungan untuk terinfeksi M. Leprae. ${ }^{9}$

Beberapa studi melaporkan bahwa progresi penyakit ke arah spektrum lepromatosa terjadi pada hampir $50 \%$ perempuan saat hamil, dan perburukan ini terutama terjadi saat trimester ketiga. ${ }^{8}$ Neuritis disertai dengan penurunan fungsi saraf secara progresif terjadi pada $50 \%$ pasien pada saat hamil, tanpa melihat status pengobatannya. Hal ini disebabkan karena kondisi imunosupresi pada saat hamil meningkatkan bacterial load sehingga menyebabkan penyebaran granuloma pada saraf dan mengakibatkan percepatan kerusakan pada saraf. 6 Dalam kasus ini, tidak didapatkan perburukan neuritis selama kehamilan.

Pengaruh MH terhadap kehamilan dapat dilihat juga dari kemungkinan terjadinya infeksi transplasental selama kehamilan. Job dkk. melaporkan placentitis lepromatous pada tiga armadillo (Dasypus novemcintus) hamil, yang tampak dari adanya $M$. leprae pada jaringan desidua dan sel trofoblas vili khorionik plasenta. Berbeda dengan armadillo, bukti transmisi transplasental $M$. leprae pada manusia lebih lemah, sebagian besar berdasarkan adanya antibodi IgA (pada 30\%) dan IgM (pada 
50\%) M. Leprae pada darah tali pusat bayi yang dilahirkan dari ibu dengan kusta tipe LL, tetapi tidak terjadi pada ibu dengan tuberkuloid leprosy. Hal tersebut kemungkinan mengindikasikan stimulasi imunologis intrauterin yang disebabkan oleh transmisi transplasental M. leprae. ${ }^{10}$ Sebuah laporan kasus oleh Chen dkk., melaporkan suatu kasus wanita hamil yang didiagnosis $\mathrm{MH}$ histoid memilih untuk menunda terapi hingga akhir kehamilan. Pemeriksaan DNA dari darah tali pusat dan IgM M. Leprae post partum didapatkan hasil positif. Pemeriksaan histopatologi plasenta menunjukkan sejumlah BTA solid. ${ }^{11}$

Terapi MDT MH MB pada kehamilan sangat penting untuk diberikan agar tidak terjadi kerusakan kulit, saraf, organ tubuh lain, dan mata. WHO merekomendasikan MDT selama kehamilan dan menyusui, serta tidak diperlukan perubahan dosis. MDT dapat terkandung dalam air susu ibu dalam jumlah kecil, tetapi tidak ada laporan efek samping obat pada bayi kecuali diskolorasi kulit sementara akibat klofazimin (karena hanya klofazimin yang dapat melalui sawar plasenta). ${ }^{7}$ Pada kasus, pemberian MDT MHMB diberikan saat memasuki trimester $2 .^{7}$

Prognosis MH pada kehamilan terkait dengan komplikasi yang terjadi pada ibu dan janin. Dimana ibu hamil dengan $\mathrm{MH}$ dapat mengalami reaksi. Reaksi tipe 1 jarang terjadi pada kehamilan, tetapi lebih sering saat laktasi karena peningkatan sistem imunitas seluler terjadi setelah 3 bulan paska melahirkan. Sedangkan reaksi tipe 2 tidak memiliki asosiasi temporal dengan kehamilan. Namun, bila terjadi reaksi ENL pada kehamilan biasanya berat dan rekuren, disertai dengan neuritis dan kerusakan saraf, dimana biasanya terjadi pada pasien dengan BI $>4$ dan pada pasien yang belum mendapatkan diterapi. ${ }^{6}$ Pada kasus ini tidak didapatkan adanya reaksi MH hingga 3 bulan paska melahirkan.

Pemeriksaan IgM dan IgG anti-PGL-1, PCR darah tali pusat dan amnion, pemeriksaan histopatologi dari tali pusat dan plasenta post partum membuktikan bayi tidak terinfeksi M.Leprae dan tidak terjadi transmisi vertikal dari ibu ke janin. Tidak didapatkan efek samping penggunaan MDT pada bayi. Penatalaksaan MDT pada kehamilan dapat mencegah transmisi MH transplasental dari ibu yang rutin mengkonsumsi MDT ke janin.

\section{SIMPULAN}

Dilaporkan sebuah kasus MH MB dengan G3P2002Ab000 yang ditegakkan secara anamnesis, pemeriksaan fisik dan pemeriksaan penunjang. Penggunaan MDT selama kehamilan dapat mencegah perburukan dan reaksi $\mathrm{MH}$, serta efektif dalam mencegah transmisi MH transplasental dari ibu ke janin.

\section{KONFLIK KEPENTINGAN}

Penulis menyatakan tidak terdapat konflik kepentingan terkait publikasi dari laporan asus ini.

\section{ETIK DALAM PUBLIKASI}

Pasien telah menandatangni lembar inform consent dan setuju untuk data medis dari pasien dipublikasikan dalam jurnal ilmiah kedokteran.

\section{DAFTAR PUSTAKA}

1. Direktorat Jenderal Pengendalian Penyakit dan Penyehat Lingkungan. Buku Pedoman Nasional Pengendalian Penyakit MH. Jakarta: Departemen Kesehatan RI. 2012.

2. World Health Organization. Universal Eliminationof Leprosy Plan Periode: 2016-2020. 2015. p.1-10.

3. World Health Organization. Global Leprosy: update on the 2012 situation. Weekly epidemiological Record. 2013. p 365-80.

4. Infodatin MH. Pusat Data dan Informasi Kementrian Kesehatan Republik Indonesia. 2015. p. 1-8.

5. Bhatia R, et al. Leprosy in Pregnancy: Obstetric Diligence is the Key. Journal of Clinical \& Diagnostic Research. 2017;20(1):10-11.

6. Adiguna MS. Relaps Morbus Hansen (MH) Tipe Borderline-Lepromatosa (BL) pada seorang perempuan hamil. E-Journal Medika. 2018;8(1):1-7.

7. Nogueira, Paula Sacha Frota, et al. Consequences of the interaction between leprosy and pregnancy. Journal of Nursing UFPE. 2012;3(1):2243-2249.

8. Brasileira S, Tropical DM, Sacha P, Nogueira F, Rejane E, Moura F, et al. Characteristics of pregnant and lactating women with leprosy. Rev Soc Bras Med Trop. 2015;20(1):48-55.

9. Anitha B, Malavika S, Kumar B, Ramesh Y. Journal of Drug Delivery and Therapeutics Current trends in drugs avoided in pregnancy. 2018. p342-50.

10. Khanna N. Leprosy in Pregnancy. In: Kumar H, Kumar B. IAL Textboook of Leprosy (Indian Association of Leprologists). $2^{\text {nd }}$ edition. New Delhi: Jaypee Brothers Medical Publisher. 2015. p. 352-258.

11. Chen Z, Kuang Y, Jiang H, Zhang W, Shi Y, Chokkakula S, Wang H. Intact Mycobacterium leprae Isolated from Placenta of a Pregnant Woman, China. Emerg Infect Dis. 2019;25(8):1604-1607.

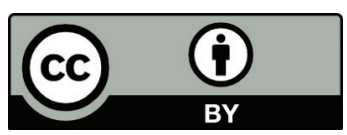

This work is licensed under a Creative Commons Attribution 